\title{
Forthcoming
}

Applied Economics Letters, 2006

\section{Private Label Price Rigidity during Holiday Periods}

\author{
Georg Müller \\ Strategic Pricing Group \\ One Lincoln Center \\ 18W140 Butterfield Rd, 15th Floor \\ Oakbrook Terrace, IL 60181 \\ USA
Mark Bergen
Department of Marketing and Logistics Management
University of Minnesota
Minneapolis, MN 55455
USA \\ Shantanu Dutta \\ Department of Marketing \\ Marshall School of Business \\ University of Southern California \\ Los Angeles, CA 90089-1421 \\ USA \\ Daniel Levy* \\ Department of Economics \\ Bar-Ilan University \\ Ramat-Gan 52900 \\ ISRAEL
}

February 14, 2005

JEL Codes: E12, E31, L11, L20, L16, M21, M31

Key Words: Price Rigidity, Holidays, Private Label, National Brand, Social Consumption

We are thankful to the participants of the NBER-CRIW conference in Cambridge, MA, and to the Price Rigidity Session participants at the American Economic Association Meetings for comments. We are particularly grateful to Walter Oi, the discussant at the NBER-CRIW conference, and to John Carlson, the discussant at the AEA meeting, for insightful comments and suggestions. We also thank Dennis Carlton, Haipeng (Allan) Chen, Bob Chirinko, Hashem Dezhbakhsh, Akshay Rao, Sourav Ray, as well as the Economics Seminar participants at Emory University and the Marketing Seminar participants at Harvard University and University of Minnesota, for useful comments and discussions. Finally, we thank the University of Chicago and Dominick's for providing access to their data set. All authors contributed equally: we rotate co-authorship. The usual disclaimer applies.

* Corresponding author: Daniel Levy, Department of Economics, Bar-Ilan University, Ramat-Gan 52900, ISRAEL, Fax:+972-3-535-3180, Tel: +972-3-531-8331, Email: Levyda@mail.biu.ac.il. 


\title{
Private Label Price Rigidity during Holiday Periods
}

\begin{abstract}
Using weekly retail transaction scanner price data from a large U.S supermarket chain, we find significantly higher retail price rigidity for private label products than for nationally branded products during the Christmas and Thanksgiving holiday periods relative to the rest of the year. The finding cannot be explained by changes in holiday period promotional practices because we find that private label promotions appear to diminish at least as much as national brands. The increased rigidity of private label products relative to national brands is only partially accounted for by increased rigidity of wholesale prices. After ruling out other potential explanations, we suggest that the higher private label price rigidity might be due to the increased emphasis on social consumption during holiday periods, raising the customers' value of nationally branded products relative to the private labels.
\end{abstract}




\section{Introduction}

Although, the study of variation in price rigidity across markets, industries, and products has received some attention in the literature, numerous authors have called for more studies in this area, arguing that understanding the reasons for the variation "... is crucial for the theory of price adjustment“ (Gordon (1981, p. 517). ${ }^{1}$

In this paper we explore variation in price rigidity between private label and nationally branded products. ${ }^{2}$ There is good reason to believe, a priori, that adjustment patterns may vary between private labels and national brands. For example, Barsky, et al. (2003) find dramatically different markups for private labels than national brands across a wide variety of product categories. Dutta, et al. (2002) document variation in cost shock pass-through patterns between private labels and national brands. ${ }^{3}$

Holiday periods provide an interesting opportunity to study variation in price rigidity because studies have documented interesting pricing patterns during holiday periods. ${ }^{4}$ For example, Müller, et al. (2002) provide evidence that retail prices are more rigid during holiday periods. ${ }^{5}$ Our discussions with retail managers also suggest that holiday periods are unusual for retailers in terms of their price adjustment activities.

We use store-level weekly time series data of actual retail and wholesale transaction prices for 4,532 products in 18 categories over a four-year period at a large Mid-western supermarket chain. We find greater price rigidity for private label products in comparison to national brands during holiday periods. We argue that this is due to the increased emphasis on social consumption during holiday periods and the corresponding substitution of branded products for private label items, which increases the value of nationally branded products relative to store brands.

The paper is organized as follows. In section 2, we describe the data. In section 3 , we report the statistical test results. In section 4, we discuss the role of social consumption in determining the extent of holiday price rigidity. Section 5 concludes.

\footnotetext{
${ }^{1}$ See also Mankiw (1985), Carlton (1986), Cecchetti (1986), Caplin and Leahy (1991), Caplin (1993), Sheshinski and Weiss (1993), Basu (1995), Kashyap (1995), Blinder, et al. (1998), Slade (1998), and Levy, et al. (2002), and the references cited therein.

${ }^{2}$ Private labels are also known as "store brands" and refer to the in-house brand, which is usually owned and sold by a particular retail supermarket chain. Nationally branded products are manufactured by big national producers and carried by most large supermarkets. Dominick's carries large number of private label products in nearly all categories we study. See Barsky, et al. (2003) for more details.

${ }^{3}$ There is also a growing literature in marketing, documenting differences between national brands and private labels. See, for example, Hoch and Banerji (1993).

${ }^{4}$ See, for example, Pashigian (1994), Warner and Barsky (1995), and Chevalier, et al. (2003).

${ }^{5}$ They, however, do not study variation in the rigidity across private label and national brand products.
} 


\section{Data}

The data come from Dominick’s, a large Mid-western supermarket chain operating 94 stores in the Chicago area with a market share of about 25 percent. ${ }^{6}$ The specific time series we use come from the scanner data of 6 stores of the chain and contain the retail prices, which are the actual transaction prices at the cash register, and information on the stores' promotional activity. The data are weekly, which parallels the chain's weekly pricing cycle, as documented by Slade (1998). ${ }^{7}$ Our data include 4,532 products in 18 categories as listed in Table 1. The data cover a four-year period, from September 14-20 (1989 to September 16-22 (1993, yielding a total of 210 weekly observations. ${ }^{8}$

There are many holidays throughout the year, but few are as closely associated with consumption of food as Thanksgiving and Christmas. Warner and Barsky (1995) and Chevalier, et al. (2003) also suggest that the two holidays are the busiest shopping periods. Indeed, our analysis shows that unit sales are 6\% higher (with $t=3.22$, significant at $1 \%$ level) during these holiday period. In fact, Dominick’s managers describe the time just before Thanksgiving through the end of Christmas as "the holiday season.” Thus, we define the 6-week period from the week before Thanksgiving through the week of Christmas as the holiday period. ${ }^{9}$

\section{Findings}

In Tables 2 and 3 we report the average number of price changes per week, during holiday and non-holiday periods for national brand and private label products, respectively. A price change here is defined as a price difference in two successive weeks. The number of price changes is calculated across all six stores to accommodate possible variation in product selection across stores. Overall, the figures indicate that

\footnotetext{
${ }^{6}$ For more details see Müller, et al. (2002), Barsky, et al. (2003), or Chevalier, et al. (2003). The data are available at www.gsb.uchicago.edu/research/mkt/MarketingHomePage.html.

${ }^{7}$ Dominick's has three price zones, and the 6 stores in our sample are in the mid-price zone. Prices for all stores within the chain are set centrally at corporate headquarters. During data collection, the chain was conducting pricing experiments, but the stores in our sample come from the "control” group, which followed the same pricing strategy. We also analyzed data for three other stores that faced a greater competition but the results we obtained were nearly identical to what we report here.

${ }^{8}$ Due to product additions and deletions, not all products have a full 210-week sales history.

${ }^{9}$ We also ran the analyses for other combinations of holiday weeks, including two weeks before Christmas and two weeks after Christmas, or focusing on each holiday individually. Our results were similar for all the alternative combinations we ran. In addition, we run a similar analysis by including other holiday periods such as Memorial Day, $4^{\text {th }}$ of July, and Labor Day, but found that the holiday period price rigidity results primarily hold for the Thanksgiving and the Christmas holidays.
} 
prices are more rigid during holiday weeks in comparison to the rest of the year, and that holds for both national brands and private labels. ${ }^{10}$

Comparing the extent of holiday price rigidity between national brand and private label products, we find that the phenomenon is more pronounced for the private label products. For example, according to Tables 2 and 3, the frequency of price changes for national brand products declines by $13 \%$ on average (with $t=-5.80$, which is significant at $1 \%$ level). For private label products, in contrast, the frequency of price changes declines by $26 \%$ on average (with $t=-4.23$, which is significant at $1 \%$ level). In some categories, the size of the difference is particularly striking. These include Analgesics, 14\% versus 58\%, Cheeses, 3\% versus 25\%, Dish Detergents, 6\% versus 38\%, Frozen Juices, 9\% versus 28\%, Laundry Detergents, 20\% versus 60\%, Paper Towels, 21\% versus 65\%, Canned Fish, 17\% versus 65\%, and Tooth Paste, 17\% versus 61\%, respectively.

We considered the possibility that the finding may be related to changes in holiday period promotional practices. For this we computed the average number of promotions per week for national brands and private labels during holiday and non-holiday periods. According to the results, which are reported in Tables 4 and 5, promotional activity goes down for both national brands and private labels for most categories. On a percentage basis, however, private label promotions go down at least as much or more as national brands with the exception of two categories, Bottled Juices and Soft Drinks.

An alternative explanation for the difference in the extent of holiday price rigidity between national brand and private label products may be related to differences in the extent of rigidity in their wholesale prices across the holiday/non-holiday periods. To examine this possibility, we calculated the average frequency of wholesale price changes during the holiday and non-holiday periods for both national brand and private label products. The wholesale price data also come from the chain's scanner database and is calculated from retail margins, which are included in the database. Despite their shortcomings, as Barsky et al. (2003) note, these wholesale price data are quite unique given that cost data are usually proprietary. According to Dominick's managers, they rely on these wholesale prices for making their pricing decisions. The results suggest that the increased rigidity of private label products relative to national brands is only partially

\footnotetext{
${ }^{10}$ This finding, however, is not the focus of this paper, because it is reported and discussed in Müller, et al. (2002). Their explanation for the greater holiday price rigidity is higher opportunity costs of price
} 
accounted for by increased rigidity of wholesale prices in either case: the wholesale price changes decline only by $5 \%$ for national brands and by $8 \%$ for private labels. This finding holds for most of the individual categories as well. ${ }^{11}$

\section{The Role of Social consumption}

We believe that at least some of the holiday price rigidity of private label products may be due to the increased emphasis on social consumption during holiday periods, which leads to an increase in the value of nationally branded products relative to store brand products. A large literature in marketing suggests that national brand products may be more valuable during holiday periods because they are consumed in social settings, with friends and family members. ${ }^{12}$

People want to leave positive impressions, and show they care, by buying the "best," or at least do not want to appear cheap. Thus, social consumption that takes place during holiday periods decreases the value of private label products relative to nationally branded products.

This makes a price change for private label products less effective during holiday periods. This will be particularly true if costs of price adjustment are indeed higher during holidays, as reported by Müller, et al. (2002). We would expect, therefore, that it would be store brand products, i.e. those products whose price changes have lower marginal value, which would see fewer price changes relative to national brands. Indeed, this is what we find.

We considered alternate explanations but they seem inconsistent with our findings. Consider Blinder et al.'s (1998) list of price rigidity theories. Theories based on the nature of contracts, imperfect information, or the nature of market interactions seem unable to explain these results because these factors are unlikely to vary between holiday and nonholiday periods and between national brand and private label products. Similarly, theories of price rigidity based on the nature of costs can be ruled out because cost factors are unlikely to vary between holiday and non-holiday periods. ${ }^{13}$ Finally, demand based price

adjustment during holiday periods. In this paper, our focus is on the differences between national brand and private label products.

${ }^{11}$ Chevalier, et al. (2003) also find that changes in wholesale prices at this chain are small in absolute as well as in relative terms.

${ }^{12}$ See, for example, Belk (1976), Cheal (1987), and Otnes, et al. (1993).

${ }^{13}$ The costs of price adjustment theory, which, as Muller, et al. (2002) have argued, lead to the holiday price rigidity for both branded and private label products, is obviously an exception. 
rigidity theories are not likely to provide a satisfactory explanation because these factors do not vary between holiday and non-holiday weeks. For example, theories of pro-cyclical elasticity of demand actually predict greater price flexibility because during holiday periods, customers become more price-sensitive. Finally, quality or other non-price aspects of the products, as far as we know, do not vary between the holiday and nonholiday weeks.

\section{Conclusion}

Using unique data set on actual retail transaction prices for thousands of products at a major retail chain, we demonstrate that prices are more rigid for private labels than for national brands during holiday periods in comparison to non-holiday periods. We find that social consumption theory provides the best explanation for the phenomenon. This explanation lends credence to the importance of customer considerations in determining price change activity as suggested by Okun's (1981) customer market theory, and more recently by Blinder, et al. (1998), Rotemberg (2002), Ball and Romer (2003), and Zbaracki, et al. (2004), who emphasize the importance of customer considerations in firm-level price setting decisions. More generally, this study underscores the importance of studying price adjustment behavior during holiday periods, and the value of holiday periods as a "natural laboratory" for economists for studying various issues. 


\section{References}

Ball, L. and D. Romer (2003) Inflation and the Informativeness of Prices, Journal of Money, Credit and Banking, 35, 177-196.

Barsky, R., M. Bergen, S. Dutta, and D. Levy (2003) What Can the Price Gap between Branded and Generic Products Tell Us about Markups? In Scanner data and price indexes, edited by M. Shapiro and R. Feenstra (New York, NY: NBER and University of Chicago Press), pp. 165-225.

Basu, S. (1995) Intermediate Goods and Business Cycles: Implications for Productivity and Welfare, American Economic Review, 85, 512-31.

Belk, R. (1976) It's the Thought that Counts: A Signed Digraph Analysis of Gift Giving, Journal of Consumer Research, 3, 155-62.

Blinder, A., E. Canetti, D. Lebow, and J. Rudd (1998), Asking about Prices: A New Approach to Understanding Price Stickiness (NY, NY: Russell Sage Foundation).

Caplin, A. (1993) Individual Inertia and Aggregate Dynamics, In Optimal Pricing, Inflation, and the Cost of Price Adjustment, edited by Eytan Sheshinski and Yoram Weiss (Cambridge, Massachusetts: The MIT Press) 19-45.

Caplin, A. and J. Leahy (1991) State-Dependent Pricing and the Dynamics of Money and Output, Quarterly Journal of Economics, 106, 683-708.

Carlton, D. (1986) The Rigidity of Prices, American Economic Review, 76, 637-58.

Cecchetti, S. (1986) The Frequency of Price Adjustment: A study of the Newsstand Prices of Magazines, Journal of Econometrics, 31, 255-274.

Cheal, D. (1987) Showing them You Love Them: Gift Giving and the Dialectic of Intimacy, Sociological Review, 35, 150-69.

Chevalier, J., A. Kashyap, and P. Rossi (2003) Why Don’t Prices Rise during Periods of Peak Demand? Evidence from Scanner Data, American Economic Review, 93, 15-37.

Dutta, S., M. Bergen, and D. Levy (2002) Price Flexibility in Channels of Distribution: Evidence from Scanner Data, J of Economic Dynamics and Control, 26, 1845-1900. Gordon, R. (1981) Output Fluctuations and Gradual Price Adjustment, Journal of Economic Literature, 19, 493-530.

Hoch, S. and S. Banerji (1993) When Do Private Labels Succeed? Sloan Management Review, 34, 57-67.

Kashyap, A. (1995) Sticky Prices: New Evidence from Retail Catalogues, Quarterly Journal of Economics, 110, 245-274.

Levy, D., S. Dutta, and M. Bergen (2002) Heterogeneity in Price Rigidity: Evidence from a Case Study Using Micro-Level Data, J of Money, Credit, and Banking, 34, 197-220. Mankiw, N.G. (1985) Small Menu Costs and Large Business Cycles: a Macroeconomic Model of Monopoly, Quarterly Journal of Economics, 100, 529-539.

Müller, G., D. Levy, S. Dutta, and M. Bergen (2002) Holiday Price Rigidity and Cost of Price Adjustment, Working Paper, No. 2002-03, Bar-Ilan University.

Okun, A. (1981) Prices and Quantities: a Macroeconomic Analysis (Washington, DC: The Brookings Institution).

Otnes, C., et al. (1993) Gift Selection for Easy and Difficult Recipients: a Social Roles Interpretation, Journal of Consumer Research, 20, 229-44.

Pashigian, P. and B. Bowen (1991) Why Are Products Sold on Sale? Explanations of Pricing Regularities, Quarterly Journal of Economics, 106, 1015-38.

Rotemberg, J. (2002) Customer Anger at Price Increases, Time Variation in the Frequency of Price Changes and Monetary Policy, NBER Working Paper No. 9320. Sheshinski, E. and Y. Weiss, Optimal Pricing, Inflation, and the Cost of Price 
Adjustment (Cambridge, Massachusetts: The MIT Press, 1993).

Slade, M. (1998) Optimal Pricing with Costly Adjustment: Evidence from Retail-Grocery Prices, Review of Economic Studies, 65, 87-107.

Warner, E. and R. Barsky (1995) The Timing and Magnitude of Retail Store Markdowns:

Evidence from Weekends and Holidays, Quarterly Journal of Economics, 110, 321-52.

Zbaracki, M., M. Ritson, D. Levy, S. Dutta, and M. Bergen (2004) Managerial and

Customer Costs of Price Adjustment: Direct Evidence from Industrial Markets,

Review of Economics and Statistics, 86, 514-533. 


\section{Table 1}

Product categories and the number of products in each category

\begin{tabular}{c|lc}
\hline No. & Product Category & Number of Products \\
\hline 1 & Analgesics & 1,362 \\
2 & Bottled Juices & 1,578 \\
3 & Cereals & 1,740 \\
4 & Cheeses & 2,262 \\
5 & Crackers & 822 \\
6 & Canned Soups & 1,824 \\
7 & Dish Detergents & 1,086 \\
8 & Frozen Entrees & 3,306 \\
9 & Frozen Juices & 702 \\
10 & Fabric Softeners & 1,176 \\
11 & Laundry Detergents & 2,160 \\
12 & Paper Towels & 510 \\
13 & Refrigerated Juices & 672 \\
14 & Soft Drinks & 3,666 \\
15 & Snack Crackers & 1,368 \\
16 & Canned Fish & 1,008 \\
17 & Tooth Pastes & 1,530 \\
18 & Toilet Tissues & 420 \\
\hline & Total & 27,192 \\
\hline
\end{tabular}

Note: The number of products is calculated using the data for all six stores combined. 
Table 2

Average number of price changes per week for national brand products

\begin{tabular}{l|rccc}
\hline Category & Non-Holiday & Holiday & $\%$ Change & $t$-statistic \\
\hline Analgesics & 74 & 64 & $-14 \%$ & $-1.33^{\mathbf{c}}$ \\
Bottled Juices & 152 & 125 & $-18 \%$ & $-1.90^{\mathbf{b}}$ \\
Cereals & 126 & 81 & $-36 \%$ & $-2.69^{\mathbf{a}}$ \\
Cheeses & 229 & 221 & $-3 \%$ & -0.36 \\
Crackers & 87 & 72 & $-17 \%$ & $-1.25^{-3}$ \\
Canned Soups & 165 & 161 & $-2 \%$ & -0.27 \\
Dish Detergents & 63 & 59 & $-6 \%$ & -0.56 \\
Frozen Entrees & 336 & 210 & $-38 \%$ & $-6.05^{\mathbf{a}}$ \\
Frozen Juices & 93 & 85 & $-9 \%$ & $-0.80^{\mathbf{b}}$ \\
Fabric Softeners & 62 & 47 & $-24 \%$ & $-2.12^{\mathbf{b}}$ \\
Laundry Detergents & 109 & 87 & $-20 \%$ & $-2.44^{\mathbf{a}}$ \\
Paper Towels & 42 & 33 & $-21 \%$ & $-1.93^{\mathbf{b}}$ \\
Refrigerated Juices & 106 & 94 & $-11 \%$ & $-1.47^{\mathbf{c}}$ \\
Soft Drinks & 655 & 607 & $-7 \%$ & $-1.55^{\mathbf{c}}$ \\
Snack Crackers & 146 & 185 & $27 \%$ & $2.04^{\mathbf{b}}$ \\
Canned Fish & 81 & 67 & $-17 \%$ & $-1.90^{\mathbf{b}}$ \\
Tooth Pastes & 111 & 92 & $-17 \%$ & -1.27 \\
Toilet Tissues & 51 & 39 & $-24 \%$ & $-2.39^{\mathbf{a}}$ \\
\hline Total & 2,688 & 2,329 & $-13 \%$ & $-5.80^{\mathbf{a}}$ \\
\hline
\end{tabular}

Note: Superscripts $a, b$, and $c$ indicate statistical significance at $1 \%, 5 \%$, and $10 \%$, respectively. The corresponding critical values are $2.33,1.64$, and 1.28 , respectively.

\section{Table 3}

Frequency of price changes per week for private label products

\begin{tabular}{l|cccc}
\hline Category & Non-Holiday & Holiday & \% Change & $t$-statistic \\
\hline Analgesics & 7.6 & 3.2 & $-58 \%$ & $-3.23^{\mathbf{a}}$ \\
Bottled Juices & 13.0 & 9.1 & $-30 \%$ & $-2.07^{\mathbf{b}}$ \\
Cereals & 11.0 & 5.7 & $-48 \%$ & $-2.98^{\mathbf{a}}$ \\
Cheeses & 56.0 & 42.0 & $-25 \%$ & $-1.97^{\mathbf{b}}$ \\
Crackers & 4.5 & 4.6 & $2 \%$ & $0.08^{-1}$ \\
Canned Soups & 8.3 & 8.3 & $0 \%$ & 0.00 \\
Dish Detergents & 7.4 & 4.6 & $-38 \%$ & $-1.83^{\mathbf{b}}$ \\
Frozen Entrees & There & are no private label products in this category & $-2.28^{\mathbf{b}}$ \\
Frozen Juices & 13.0 & 9.4 & $-28 \%$ & $-4.19^{\mathbf{a}}$ \\
Fabric Softeners & 5.4 & 2.3 & $-57 \%$ & $-4.01^{\mathbf{a}}$ \\
Laundry Detergents & 4.0 & 1.6 & $-60 \%$ & $-3.81^{\mathbf{a}}$ \\
Paper Towels & 2.0 & 0.7 & $-65 \%$ & $-1.39^{\mathbf{c}}$ \\
Refrigerated Juices & 8.0 & 6.2 & $-23 \%$ & $-0.91^{\mathbf{b}}$ \\
Soft Drinks & 72.0 & 62.0 & $-14 \%$ & $-1.73^{\mathbf{b}}$ \\
Snack Crackers & 4.9 & 3.1 & $-37 \%$ & $-3.64^{\mathbf{a}}$ \\
Canned Fish & 3.7 & 1.3 & $-65 \%$ & $-2.29^{\mathbf{b}}$ \\
Tooth Pastes & 1.8 & 0.7 & $-61 \%$ & $-1.88^{\mathbf{b}}$ \\
Toilet Tissues & 3.0 & 1.5 & $-50 \%$ & $-4.23^{\mathbf{a}}$ \\
\hline Total & 225.6 & 166.3 & $-26 \%$ & \\
\hline
\end{tabular}

Note: Superscripts $a, b$, and $c$ indicate statistical significance at $1 \%, 5 \%$, and $10 \%$, respectively. The corresponding critical values are $2.33,1.64$, and 1.28 , respectively. 
Table 4

Frequency of promotions per week for national brand products

\begin{tabular}{l|cccc}
\hline Category & Non-Holiday & Holiday & \% Change & $t$-statistic \\
\hline Analgesics & 18 & 32 & $78 \%$ & $2.89^{\mathbf{a}}$ \\
Bottled Juices & 79 & 61 & $-23 \%$ & $-2.41^{\mathbf{a}}$ \\
Cereals & 66 & 40 & $-39 \%$ & $-4.11^{\mathbf{a}}$ \\
Cheeses & 85 & 96 & $13 \%$ & $0.77^{\mathbf{a}}$ \\
Crackers & 39 & 59 & $51 \%$ & $4.96^{\mathbf{a}}$ \\
Canned Soups & 57 & 100 & $75 \%$ & $1.67^{\mathbf{b}}$ \\
Dish Detergents & 32 & 26 & $-19 \%$ & $-1.64^{\mathbf{b}}$ \\
Frozen Entrees & 172 & 75 & $-56 \%$ & $-4.73^{\mathbf{a}}$ \\
Frozen Juices & 46 & 48 & $-4 \%$ & $-4.67^{\mathbf{a}}$ \\
Fabric Softeners & 34 & 20 & $-39 \%$ & $-7.12^{\mathbf{a}}$ \\
Laundry Detergents & 69 & 42 & $-4 \%$ & -0.43 \\
Paper Towels & 26 & 25 & $-21 \%$ & $-2.88^{\mathbf{a}}$ \\
Refrigerated Juices & 56 & 44 & $-12 \%$ & $-2.07^{\mathbf{b}}$ \\
Soft Drinks & 357 & 314 & $83 \%$ & $2.15^{\mathbf{b}}$ \\
Snack Crackers & 58 & 106 & $300 \%$ & $18.45^{\mathbf{a}}$ \\
Canned Fish & 23 & 92 & $-33 \%$ & $-3.16^{\mathbf{a}}$ \\
Tooth Pastes & 83 & 56 & $0 \%$ & 0.00 \\
Toilet Tissues & 28 & 28 & $-5 \%$ & -1.26 \\
\hline Total & 1,328 & 1,264 & & \\
\hline
\end{tabular}

Note: Superscripts $a, b$, and $c$ indicate statistical significance at $1 \%, 5 \%$, and $10 \%$, respectively. The corresponding critical values are $2.33,1.64$, and 1.28 , respectively.

Table 5

Frequency of promotions per week for private label products

\begin{tabular}{l|cccc}
\hline Category & Non-Holiday & Holiday & \% Change & $t$-statistic \\
\hline Analgesics & 8.2 & 14.0 & $71 \%$ & $1.47^{\mathbf{c}}$ \\
Bottled Juices & 7.7 & 6.2 & $-19 \%$ & -1.23 \\
Cereals & 5.3 & 2.8 & $-47 \%$ & $-2.64^{\mathbf{a}}$ \\
Cheeses & 25.0 & 28.0 & $12 \%$ & 0.55 \\
Crackers & 4.8 & 4.0 & $-17 \%$ & -0.67 \\
Canned Soups & 1.8 & 2.9 & $61 \%$ & 0.73 \\
Dish Detergents & 2.6 & 3.7 & $42 \%$ & 0.67 \\
Frozen Entrees & There & are no private label products in this category & -1.20 \\
Frozen Juices & 8.9 & 7.0 & $-21 \%$ & -1.16 \\
Fabric Softeners & 1.4 & 0.8 & $-43 \%$ & $-2.16^{\mathbf{b}}$ \\
Laundry Detergents & 0.9 & 0.3 & $-67 \%$ & $-5.47^{\mathbf{a}}$ \\
Paper Towels & 2.2 & 0.3 & $-86 \%$ & $-1.49^{\mathbf{c}}$ \\
Refrigerated Juices & 9.2 & 7.0 & $-24 \%$ & -0.22 \\
Soft Drinks & 50.0 & 48.0 & $-4 \%$ & 0.28 \\
Snack Crackers & 0.4 & 0.5 & $25 \%$ & $-4.13^{\mathbf{a}}$ \\
Canned Fish & 3.1 & 0.5 & $-84 \%$ & $-5.50^{\mathbf{a}}$ \\
Toothpastes & 1.4 & 0.0 & $-100 \%$ & $-5.26^{\mathbf{a}}$ \\
Toilet Tissues & 1.1 & 0.0 & $-6 \%$ & -0.67 \\
\hline Total & 134.0 & 126.0 & & \\
\hline
\end{tabular}

Note: Superscripts $a, b$, and $c$ indicate statistical significance at $1 \%, 5 \%$, and $10 \%$, respectively. The corresponding critical values are $2.33,1.64$, and 1.28 , respectively. 